Geology, Geophysics \& Environment • 2012 • Vol. 38 • No. 1 • 23-34

http://dx.doi.org/10.7494/geol.2012.38.1.23

\title{
PROBLEMY HYDROGEOLOGICZNE I GEOTECHNICZNE ZWIĄZANE Z ZAWODNIENIEM ZABYTKOWYCH SZYBÓW KOPALNI SOLI WIELICZKA NA PRZYKŁADZIE SZYBU GÓRSKO
}

\author{
Hydrogeological and geotechnical issues \\ associated with water accumulation in the historic shafts \\ of the Wieliczka Salt Mine: the Górsko Shaft case
}

Kajetan d'OBYRN ${ }^{1,2}$ \& Jerzy PRZYBYLO ${ }^{1}$

\author{
${ }^{1}$ Kopalnia Soli „,Wieliczka” SA; Park Kingi 1, 32-020 Wieliczka \\ ${ }^{2}$ Politechnika Krakowska; ul. Warszawska 24, 31-155 Kraków; \\ e-mail: kajetan.dobyrn@kopalnia.pl,jerzy.przybylo@kopalnia.pl
}

\begin{abstract}
Treść: Szyb Górsko został zgłębiony do głębokości poziomu I w pierwszej połowie XVII wieku i ukończono go prawdopodobnie w 1622 roku. W XIX wieku szyb pogłębiano, a w 1954 roku został zasypany do głębokości około 6 m p.p.t. Na podszybiach szybu oraz w pobliskiej komorze Fryderyk August rejestrowano wycieki solanek oraz okresowo wynoszony materiał skalny w postaci iłów pylastych. Teren wokół szybu systematycznie osiada, a rejestrowane średnie obniżenia terenu wynoszą ok. $13 \mathrm{~mm} / \mathrm{rok}$. W grudniu 2002 roku tempo osiadań wzrosło, powodując spękania budynku nadszybia. W lutym 2011 r. został opracowany projekt techniczny doszczelnienia szybu. Zaprojektowano 83 otwory doszczelniające otaczające szyb, o głębokości $18 \mathrm{~m}$ oraz trzy otwory kontrolne w tarczy szybu. Prace cementacyjne zaplanowano w czterech strefach głębokościowych przy użyciu zaczynów cementowych, a realizację projektu rozpoczęto $\mathrm{w}$ grudniu $2011 \mathrm{r}$.
\end{abstract}

Słowa kluczowe: miocen, Wieliczka, kopalnia soli, zagrożenie wodne, stabilizacja górotworu

\begin{abstract}
The Górsko Shaft was excavated to the depth of Level I in the first half of the seventeenth century, and was probably completed in 1622. in the nineteenth century, the shaft was extended. in 1954, the Górsko Shaft was filled up to a depth of approximately 6 meters below the ground. Inflows out of the Górsko Shaft were first observed in the shaft bottom and in Fryderyk August chamber. Through suffusion and leaching salt formations, migratory waters caused soil settling and structural damage to the shaft top building. In February 2011, a technical design for the sealing of the Gorsko Shaft was developed, which calls for cementing work and the elimination of surface water inflow through the shaft into the mine workings. Engineering work related to the restriction of the flow of water into the Górsko Shaft began in December 2011.
\end{abstract}

Key words: Miocene, Wieliczka, salt mine, water hazard, the stabilization of rock 


\section{WSTĘP}

Wody migrujące szybem Górsko oraz wokół niego nie zagrażają bezpośrednio istnieniu wielickich podziemi, jednak ich infiltracja w głąb górotworu oraz zmiany wielkości dopływu i zawartości $\mathrm{NaCl}$ powodują konieczność ich ujmowania i pompowania na powierzchnię. Migrujące przez stulecia wody wypłukując grunt (zjawiska sufozji) oraz ługując utwory solne, wraz z procesem zaciskania się wyrobisk poeksploatacyjnych spowodowały osiadanie terenu i uszkodzenia konstrukcji budynku nadszybia. Zagadnienie dopływu wód do szybu Górsko i wynikające z tej przyczyny problemy zawodnienia pobliskich wyrobisk w kopalni, a także zjawiska geologiczno-inżynierskie w otoczeniu szybu na powierzchni stanowią przykład problemów hydrogeologicznych i geotechnicznych występujących w różnym nasileniu w otoczeniu wszystkich szybów Kopalni Soli Wieliczka.

\section{RYS HISTORYCZNY}

Szyb Górsko został zgłębiony do głębokości poziomu I w pierwszej połowie XVII wieku, ukończono go za administracji żupnika Andrzeja Górskiego, prawdopodobnie w 1622 roku. Wyrobiska w jego najbliższym otoczeniu na poziomie I powstały w XVII i w XVIII wieku (Fig. 1).

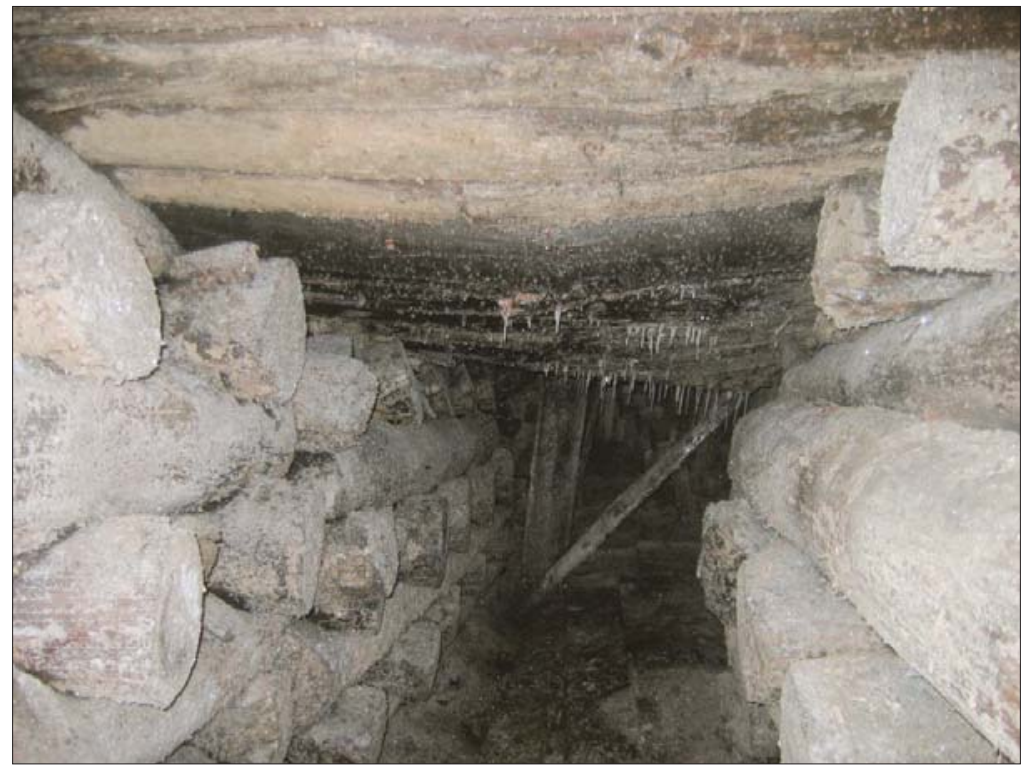

Fig. 1. Wyrobiska na I poziomie kopalni znajdujące się w otoczeniu szybu Górsko (fot. J. Przybyło).

Fig. 1. Excavation on the I level in the mine located in the vicinity of the Górsko Shaft (phot. J. Przybyło) 
Szyb w XIX wieku pogłębiano, początkowo do poziomu II niższego, następnie w okresie do 1836 roku do poziomu IV. W latach 90. XIX stulecia oraz w pierwszym dziesięcioleciu XX wieku dokonano remontu jego obudowy. W 1899 roku drewnianą kletę zastąpiono murowanym nadszybiem. W latach 1912-1914 przedłużono zbudowaną w 1902 roku kolejkę linową z pobliskiej piaskowni Psia Górka tak, by dochodziła do szybu, i od 1914 roku zaczęto opuszczać nim do kopalni piasek do podsadzania wyrobisk, co po przerwie w okresie I wojny światowej kontynuowano w latach międzywojennych. W 1954 roku szyb Górsko został zasypany do głębokości około 6 m p.p.t. (Müller 1935, Dziwik 1984, Charkot 2003).

\section{BUDOWA GEOLOGICZNA GÓROTWORU W OTOCZENIU SZYBU GÓRSKO}

W profilu geologicznym szybu występują utwory czwartorzędu, wykształcone w postaci glin pylastych i iłów pylastych, a następnie kolejno utwory otuliny iłowo-gipsowej, złoże bryłowe z zubrami i bryłami soli zielonej i od wysokości poziomu II niższego w głąb górotworu utwory złoża pokładowego (Fig. 2).

Szczegółowe wykształcenie utworów czwartorzędowych w najbliższym otoczeniu szybu rozpoznano otworami wiertniczymi wierconymi do stropowych partii neogenu (Fig. 2) (Hrebenda 2005). Badania geologiczne najbliższego otoczenia szybu Górsko wykazały obecność w warstwach czwartorzędu glin pylastych. Ten drobnoziarnisty, luźny osad podatny jest na sufozję i po odsłonięciu zachowuje się jak gęsta ciecz. Warstwę tę górnicy nazwali „zydzem”. Podczas głębienia wyrobiska w XVII wieku trudności sprawiało przejście przez tę warstwę, a dopływ wody z tych utworów określano jako znaczny. W celu sczerpania wody dopływającej do drążonego szybu wykonano w pobliżu studnię odwadniającą połączoną z szybem podziemnym chodnikiem, tzw. stułą (Charkot 2003).

\section{WARUNKI HYDROGEOLOGICZNE W REJONIE SZYBU GÓRSKO}

Podstawowym źródłem zawodnienia szybu Górsko i otaczających go wyrobisk są utwory czwartorzędowe. Na zawodnienie rejonu i procesy geologiczno-inżynierskie zachodzące w górotworze mogły także mieć wpływ płynący w pobliżu szybu potok oraz zapadlisko dopowierzchniowe komory Słaboszów, powstałe w 1698 roku, znajdujące się kilkadziesiąt metrów na zachód od szybu (Kolasa \& Kubik 1983).

Obserwacje dopływu solanek na podszybiach szybu Górsko prowadzone były w sposób nieregularny. W Archiwum Działu Geologicznego kopalni znajdują się dane z lat 1943, 1944, 1948, 1949. Następnie do roku 1981 brak jest informacji o wielkościach dopływu wód do podszybi szybu. Od 1981 roku obserwacje prowadzone są regularnie, z przerwą w roku 1992 (Fig. 3). 


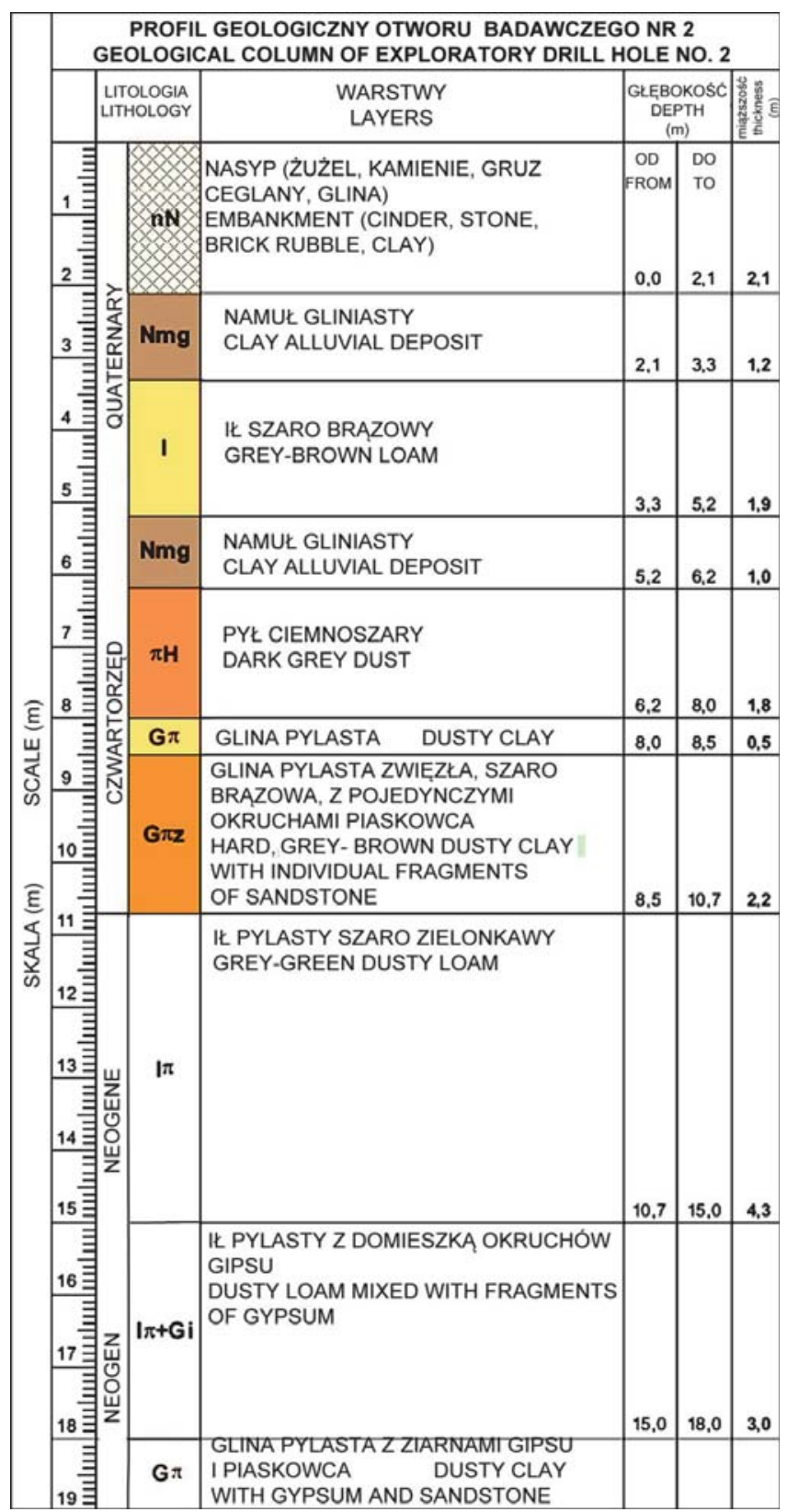

Fig. 2. Profil geologiczny otworu badawczego nr 2 znajdującego się bezpośrednio przy szybie Górsko (Hrebenda 2005)

Fig. 2. Geological column of exploratory drill hole no. 2 located close to the Górsko Shaft (Hrebenda 2005) 


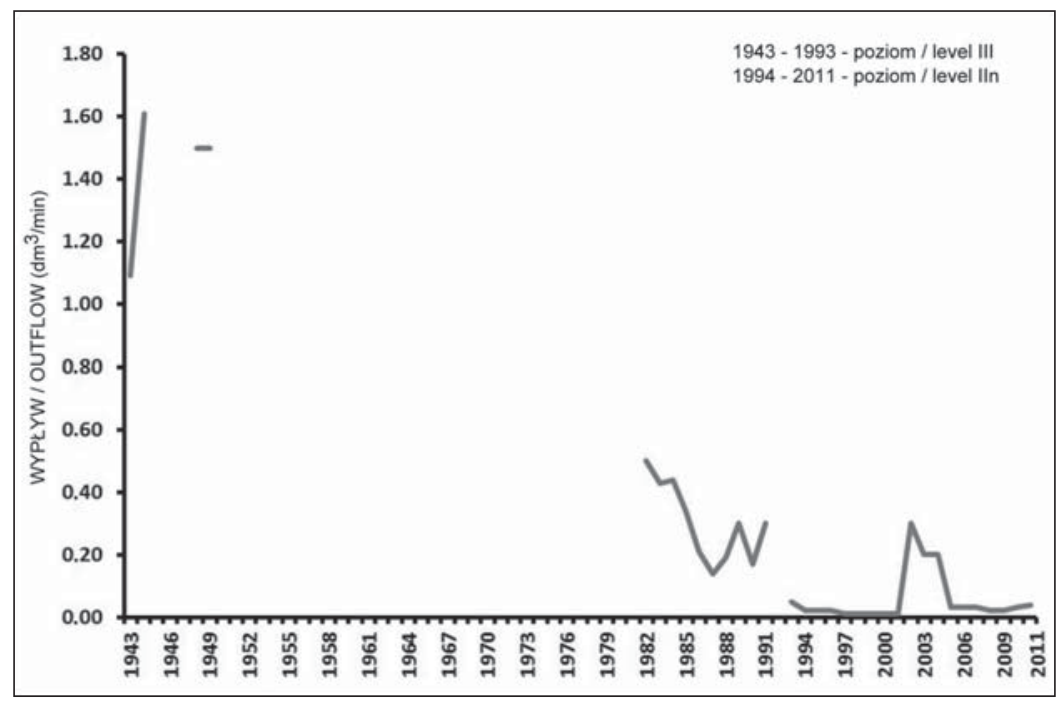

Fig. 3. Wykres dopływów solanki rejestrowanych na podszybiach szybu Górsko na poziomach IIn oraz III

Fig. 3. Graph of registered brine inflows on Górsko Shaft pits on levels IIn and III

Wycieki wód z szybu Górsko pierwotnie obserwowano na podszybiu poziomu III. Na mapie poziomu III z lat 30. XX wieku na podszybiu szybu widnieje wyciek nr 63 o wydatku $1.59 \mathrm{dm}^{3} / \mathrm{min}$. Według obserwacji z lat 1943-1944 na podszybiu poziomu III występowały dopływy rzędu $0.66-1.6 \mathrm{dm}^{3} / \mathrm{min}$, a w latach $1948-49$ o wielkości około $1.5 \mathrm{dm}^{3} / \mathrm{min}$. Do połowy XX wieku dopływy do kopalni pochodzące spoza granic złoża określano jako „dzikie dopływy". Wielkość dopływu rejestrowana była w książkach obserwacji wypływów (Dzikie doptywy w kopalni w Wieliczce za lata 1943-1944, 1948-1959).

Podszybia szybu na poziomach I oraz IV nie są obecnie dostępne. Na poziomie I do roku 1984 obserwowano wykroplenia pełnonasyconej solanki o wielkości maksymalnie 20 kropli/min (WI-Górsko). Wycieki związane z szybem obserwowane są obecnie w rejonie podszybi na poziomie II niższym oraz III (Fig. 4) (Rejestr wycieków kopalnianych poziom IIn. Kopalnia Soli Wieliczka za lata 1983-2003, Rejestr wycieków kopalnianych. Książka kontroli wycieków na poziomie IIn za lata 2004-2012).

Po zasypaniu szybu w 1954 roku dopływy rejestrowane na jego podszybiach charakteryzowały się zróżnicowanym wydatkiem: od wykropleń do około $2 \mathrm{dm}^{3} / \mathrm{min}$, a także zmiennością dróg przepływu. Można z dużym prawdopodobieństwem przyjąć, analogicznie jak w przypadku innych szybów, że w najbliższym sąsiedztwie szybu istnieją różnych rozmiarów pustki i szczeliny w górotworze pochodzące zarówno z czasów budowy szybu, jak i powstałe wskutek eksploatacji rejonu, a także utworzone w wyniku wymywania materiału skalnego przez infiltrujące z powierzchni wody. W wodach odbieranych na podszybiach szybu Górsko pojawiały się okresowo części stałe (wypłukane gliny pylaste). 


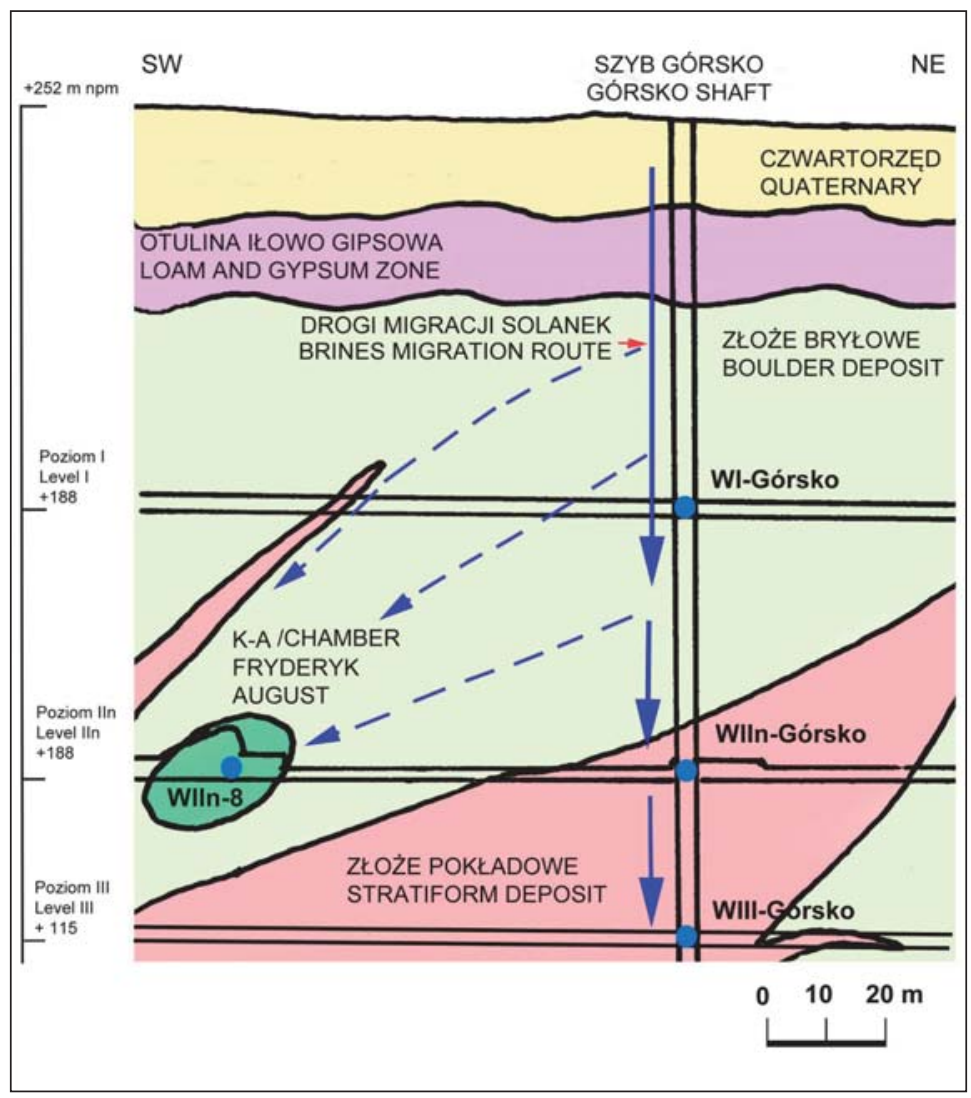

Fig. 4. Schemat migracji solanek i rejestrowanych wycieków w rejonie szybu Górsko (Przybyło 2011)

Fig. 4. Scheme of the migration of brines and registered spill in the area of the Gorrsko Shaft (Przybyło 2011)

Obecnie nie obserwuje się znaczących zjawisk hydrogeologicznych na poziomie III, w miejscu rejestracji dopływu w latach 40. XX wieku. Solanki odbierane są na poziomie II niższym jako wyciek WIIn-Górsko w rejonie podszybia (Książka kontroli zagrożenia wodnego w nieczynnych szybach w Kopalni Wieliczka za lata 1981-2012).

Wyciek WIIn-Szyb Górsko to obecnie wykroplenia pełnonasyconej solanki w rejonie podszybia w ilości około $50 \mathrm{kropli} / \mathrm{min}$, a także dopływ pełnonasyconej solanki do rząpia o wydatku około $0.04 \mathrm{dm}^{3} / \mathrm{min}$. Wyciek WIII-Szyb Górsko to wykroplenia pełnonasyconej solanki w ilości 4-10 kropli/min (Rejestr wycieków kopalnianych poziom IIn. Kopalnia Soli Wieliczka za lata 1983-2003, Rejestr wycieków kopalnianych. Książka kontroli wycieków na poziomie IIn za lata 2004-2012).

W latach 1943-2011 zaobserwowano dużą zmienność zasolenia wód, wynikającą prawdopodobnie ze zmian dróg migracji wód w górotworze w rejonie szybu. W latach 1943-1949, 
czyli przed likwidacją szybu, zasolenie obserwowanych wód (zawartość $\mathrm{NaCl}$ ) nie przekraczało $40 \mathrm{~g} / \mathrm{dm}^{3}$. Po likwidacji szybu drogi migracji wód uległy zmianie, co spowodowało wzrost zasolenia (Tab. 1) (Książka kontroli zagrożenia wodnego w nieczynnych szybach w Kopalni Wieliczka).

Tabela (Table) 1

Wielkość nasycenia solanek obserwowanych na podszybiach szybu Górsko w latach 1943-2011

Size of saturating brines observed on Górsko Shaft in years 1943-2011

\begin{tabular}{|c|c|c|}
\hline $\begin{array}{l}\text { Data } \\
\text { Date }\end{array}$ & $\begin{array}{l}\mathrm{NaCI} \\
{\left[\mathrm{g} / \mathrm{dm}^{3}\right]}\end{array}$ & $\begin{array}{c}\text { Miejsce poboru prób } \\
\text { Place of sampling }\end{array}$ \\
\hline 1943 & 39.38 & poz. Ill \\
\hline 1944 & 30.47 & poz. III \\
\hline 1948 & 30.00 & poz. Ill \\
\hline 1949 & 30.00 & poz. Ill \\
\hline 1983 & 309.70 & poz. Ill \\
\hline 1985 & 302.70 & poz. Ill \\
\hline 1986 & 304.00 & poz. Ill \\
\hline 1993 & 303.35 & poz. Iln \\
\hline 2000 & 306.86 & poz. Iln \\
\hline 2002 & 309.78 & poz. Iln \\
\hline 2004 & 309.78 & poz. Iln \\
\hline 2005 & 309.78 & poz. Iln \\
\hline 2006 & 308.32 & poz. Iln \\
\hline 2007 & 303.94 & poz. Iln \\
\hline 2008 & 306.86 & poz. Iln \\
\hline 2009 & 309.78 & poz. Iln \\
\hline 2010 & 309.78 & poz. Iln \\
\hline 2011 & 309.78 & poz. Iln \\
\hline
\end{tabular}

Solanki z szybu Górsko prawdopodobnie migrują także do komory Fryderyk August (wyciek WIIn-8) znajdującej się na południe od szybu (Fig. 4). Drogami migracji mogą być szczeliny i spękania wynikające z poeksploatacyjnego odprężenia górotworu. W najbliższym otoczeniu komory Fryderyk August jedynym możliwym źródłem dopływu wód do komory 
jest szyb Górsko - nie stwierdzono w tym rejonie innych oznak migracji wód. W solankach wycieku WIIn-8 okresowo obserwuje się materiał ilasto-pylasty z warstw czwartorzędowych. Analiza chemiczna wód pobranych w roku 2011 wykazuje niepełne ich nasycenie (258.64 g/dm $\left.{ }^{3}\right)$. W latach 1969-2010 wielkość wypływu wód w wycieku WIIn-8 nie przekraczała $0.10 \mathrm{dm}^{3} / \mathrm{min}$ (d'Obyrn 2010), ale w roku 2011 zaobserwowano wzrost wydatku do około $0.30 \mathrm{dm}^{3} / \mathrm{min}$ (Fig. 5).

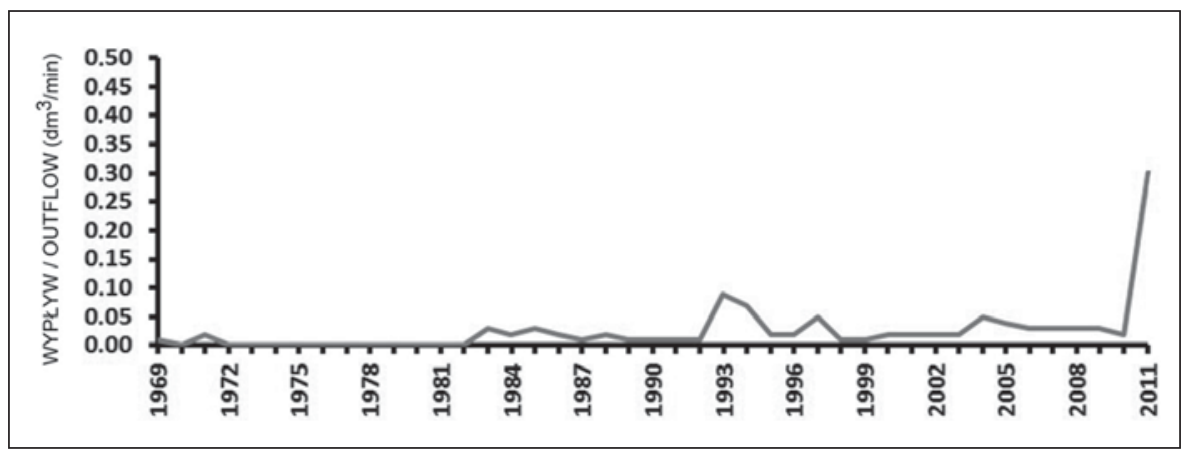

Fig. 5. Wielkość wydatku wycieku WIIn-8 obserwowana w latach 1969-2011

Fig. 5. Amount of the expense of the WIIn-8 leak observed in 1969-2011

\section{WZMOCNIENIE I USZCZELNIENIE GÓROTWORU W OTOCZENIU SZYBU GÓRSKO}

Budynek nadszybia położony jest w niecce, co determinuje kierunek spływu wód opadowych. Teren wokół szybu systematycznie osiada, a rejestrowane średnie obniżenia wynoszą $13 \mathrm{~mm} /$ rok. Pod koniec lat 70. XX wieku stwierdzono przy szybie niewielkie zapadnięcie terenu, a w rurze szybowej w latach 80 . obniżenie się poziomu wypełniającego go materiału. W grudniu 2002 roku zaobserwowano spękania budynku nadszybia, spowodowane zintensyfikowaniem osiadań. Zjawiska te wymusiły wykonanie w styczniu i lutym 2003 roku prac zabezpieczających polegających na likwidacji pustek wokół szybu dwoma pierścieniami otworów wierconych do głębokości $3 \mathrm{~m}$, którymi zatłaczano poliuretan. Pustki w rurze szybowej na odcinku 16 m zlikwidowano spoiwem mineralno-cementowym Teksil oraz pianą mineralno-cementową Durafoan. Wlot szybu został przykryty płytą betonową o grubości około $0.5 \mathrm{~m}$. Prace te miały doprowadzić do ograniczenia dopływu wód do szybu i wyrobisk kopalni. Ich efektem był spadek tempa osiadania terenu w jego otoczeniu z ok. $25 \mathrm{~mm} / \mathrm{miesiąc}$ do ok. 5 mm/miesiąc (Stawarczyk 2003).

W lutym 2011 r. został opracowany projekt techniczny doszczelnienia szybu Górsko. Zakłada on prace cementacyjne mające doprowadzić do likwidacji dopływu wód powierzchniowych przez szyb i jego otoczenie do wyrobisk kopalni. Prace zaplanowano tak, aby zachować 
substancję budynku nadszybia i wieży szybowej wpisanych do rejestru zabytków. Zadaniem cementacji doszczelniającej w szybie Górsko jest uzyskanie płaszcza uszczelniającego wokół rury szybowej, zespolenie masywu skalnego tak, by uzyskać parametry zapewniające stabilność górotworu, oraz zlikwidowanie dopływu wód powierzchniowych do wyrobisk kopalni. Zaprojektowano 83 otwory doszczelniające otaczające szyb, sięgające głębokości $18 \mathrm{~m}$ oraz trzy otwory kontrolne w tarczy szybu. Prace cementacyjne będą prowadzone w czterech strefach głębokościowych, zaczynami cementowymi z domieszkami przyspieszającymi wiązanie cementu. Otwory cementacyjne zaplanowano na obwodzie obmurza dwoma pierścieniami (odpowiednio 39 i 44 otwory) w trójkącie $0.5 \mathrm{~m} \times 0.5 \mathrm{~m} \times 0.5 \mathrm{~m}$, co pozwoli na uzyskanie szczelnego płaszcza o grubości około $1.5 \mathrm{~m}$ na zewnątrz obudowy murowej szybu (Fig. 6). Przy rozmieszczeniu otworów cementacyjnych, którymi prowadzone będzie doszczelnienie, i doborze zaczynów oraz ciśnienia zatłaczania kierowano się przede wszystkim warunkiem niedopuszczenia do rozszczelnienia poszczególnych warstw skalnych. Przyjęto ciśnienie cementacji w zakresie 0.016-0.20 MPa, w zależności od strefy cementacji (Parchanowicz \& Kokot 2001, d'Obyrn 2010).

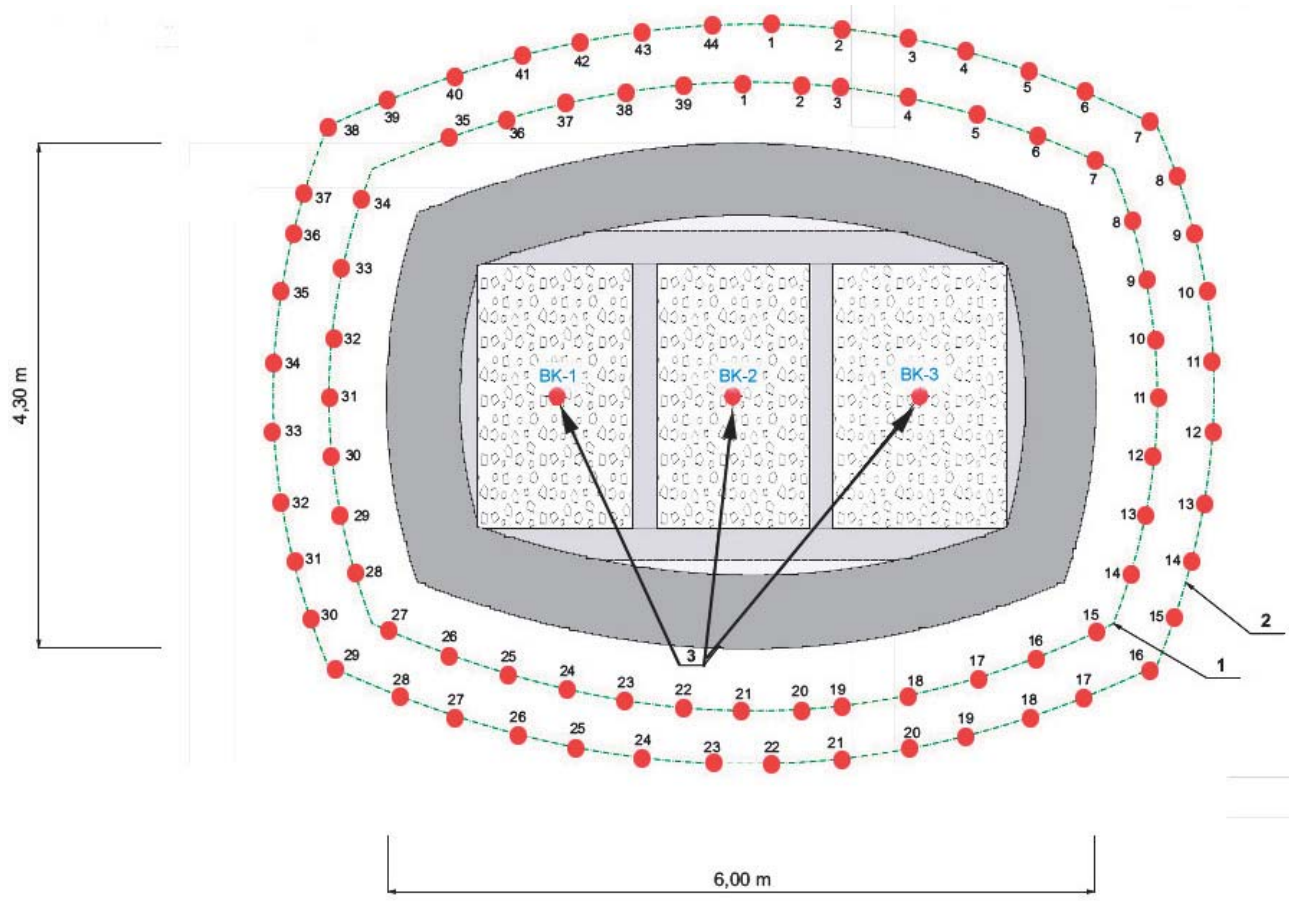

Fig. 6. Rozmieszczenie otworów cementacyjnych $(1,2)$ i kontrolnych $(3)$ w nadszybiu szybu Górsko (Parchanowicz \& Kokot 2001)

Fig. 6. Location of cementation $(1,2)$ and inspection (3) holes in Górsko Shaft (Parchanowicz \& Kokot 2001) 


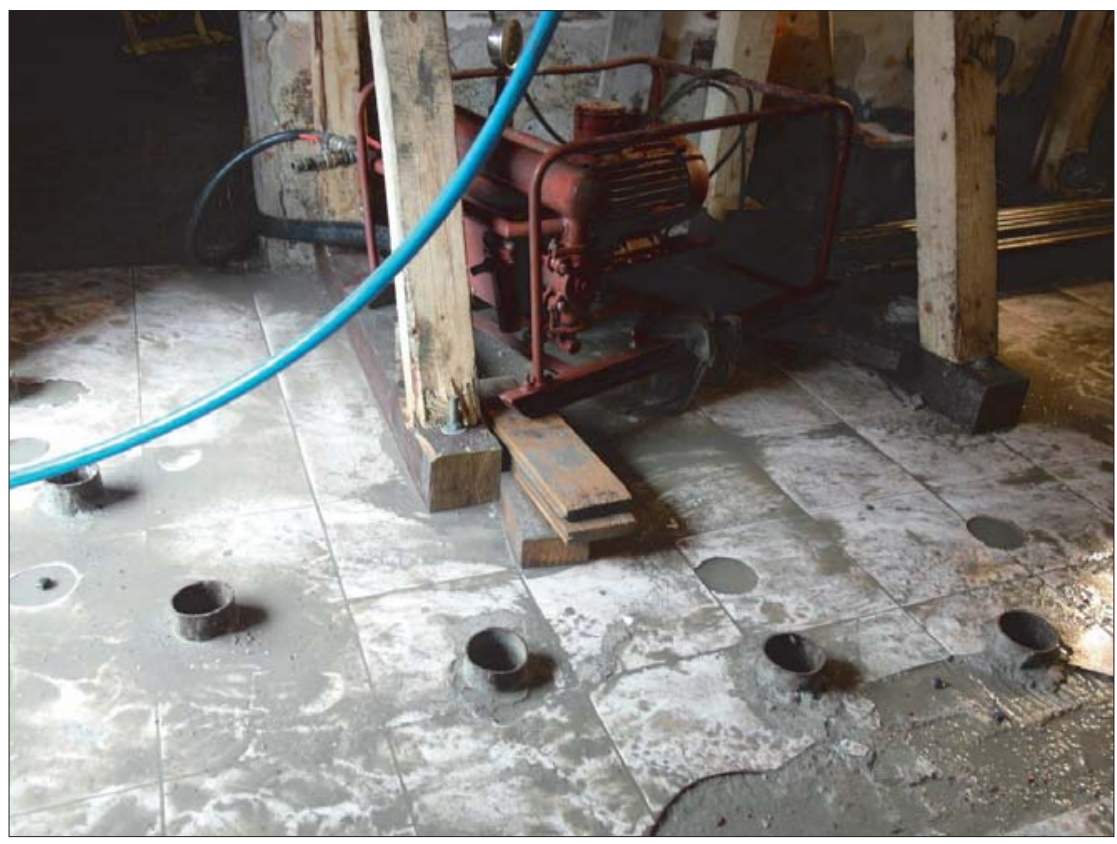

Fig. 7. Otwory cementacyjne pierwszego pierścienia - stan na marzec 2012 r. (fot. J. Przybyło)

Fig. 7. Cementation holes of the first ring - a state for March 2012 (phot. J. Przybyło)

Prace inżynieryjne związane z ograniczeniem dopływu wód do szybu Górsko rozpoczęły się w grudniu 2011 r. Obecnie (marzec 2012 r.) trwają prace przy pierwszym pierścieniu cementacyjnym (Fig. 7). Zakończenie prac cementacyjnych w szybie Górsko planowane jest na czwarty kwartał 2012 r.

\section{LITERATURA}

Charkot J., 2003. Szyb Górsko - świadek górniczej historii miasta. Żupy. Kwartalnik Muzeum Żup Krakowskich Wieliczka, 14, 3-4.

d'Obyrn K., 2010. The impact of old mine shafts on the accumulation of water in mined excavations and terrain surface based on the example of the Górsko shaft in the Wieliczka Salt Mine. XXXVIII International Association of Hydrogeologist World Congress, University of Silesia Press, Kraków.

Dzikie dopływy w kopalni w Wieliczce za lata 1943-1944, 1948-1959. Archiwum Działu Geologicznego KS Wieliczka.

Dziwik K., 1984. Zabezpieczenie Kopalni Soli w Wieliczce podsadzką w latach 1832-1939 (zarys historyczny). W: Studia i materiały do dziejów Żup Solnych w Polsce, XIII, Muzeum Żup Krakowskich Wieliczka, 107-152. 
Hrebenda M., 2005. Dokumentacja geologiczno-inżynierska dla rejonu szybu Górsko w Wieliczce. Krakowskie Przedsiębiorstwo Geologiczne „ProGeo” Sp. z o.o., Archiwum Działu Geologicznego KS Wieliczka (maszynopis).

Kolasa K. \& Kubik K., 1983. Poeksploatacyjne zapadliska wielickie. W: Studia i materiały do dziejów Żup Solnych w Polsce, XII, Muzeum Żup Krakowskich Wieliczka, 7-62.

Ksiązka kontroli zagrożenia wodnego $w$ nieczynnych szybach $w$ Kopalni Wieliczka za lata 1981-2012. Archiwum Działu Geologicznego KS Wieliczka.

Müller A., 1935. Historia saliny wielickiej. Archiwum Działu Geologicznego KS Wieliczka (maszynopis).

Przybyło J., 2011. Schemat migracji solanek i rejestrowanych wycieków w rejonie szybu Górsko. Archiwum Działu Geologicznego KS Wieliczka

Rejestr wycieków kopalnianych poziom IIn. Kopalnia Soli Wieliczka za lata 1983-2003. Archiwum Działu Geologicznego KS Wieliczka.

Rejestr wycieków kopalnianych. Książka kontroli wycieków na poziomie IIn za lata 20042012. Archiwum Działu Geologicznego KS Wieliczka.

Stawarczyk Z., 2003. Analiza dotychczasowych deformacji budynku przy ul Górsko 12 a na podstawie prowadzonych obserwacji. Archiwum Działu Mierniczego KS Wieliczka (maszynopis).

Parchanowicz J. \& Kokot B., 2001. Dokumentacja rewitalizacji budynku nadszybia szybu „Górsko” wraz z projektem uszczelnienia zlikwidowanego szybu w przedziale od powierzchni do stropu trzeciorzędu. Archiwum Działu Geologicznego KS Wieliczka.

\section{Summary}

The Górsko Shaft was excavated to the depth of Level I in the first half of the seventeenth century, and was probably completed in 1622. Workings in its immediate vicinity on Level I originated in the seventeenth and eighteenth centuries. in the nineteenth century, the shaft was extended, initially to lower Level II, then, ending in 1836, to Level IV.

In 1954, the Górsko Shaft was filled up to a depth of approximately 6 meters below the ground. The geological profile of the shaft includes Quaternary formations, in the form of silty clays, followed by silt, silt-gypsum buffer zone, the blocky deposit with Zuber (silthalite) and green-salt blocks, and, starting at lower Level II, layered deposit formations (Figs 1-2). Inflows out of the Górsko Shaft, of the volume of $1.59 \mathrm{dm}^{3} / \mathrm{min}$, were first observed in Level III shaft bottom. Until 1954, the inflow volume varied between $0.66 \mathrm{dm}^{3} / \mathrm{min}$ and $2.0 \mathrm{dm}^{3} / \mathrm{min}$. After the shaft was backfilled, the inflow varied between dripping and approx. $2.0 \mathrm{dm}^{3} / \mathrm{min}$. Inflows from the shaft were observed in shaft bottom area at lower Level II and Level III (Tab. 1, Fig. 3). Probably, the inflow of brines observed in Fryderyk August chamber on lower Level II (WIIn-8) is connected with the Górsko Shaft (Figs 4-5).

Through suffusion and leaching salt formations, migratory waters caused soil settling and structural damage to the shaft top building. 
In February 2011, a technical design for the sealing of the Górsko Shaft was developed, which calls for cementing work and the elimination of surface water inflow through the shaft into the mine workings (Fig. 6).

The task of cementing in the Górsko Shaft is:

- to obtain the mantle insert around the pipe shaft,

- the incorporation of rock massif to the parameters to ensure the stability of the rock,

- elimination of the supply of surface water by the glass to the workings of the mine.

Engineering work related to the restriction of the flow of water into the Gorsko Shaft began in December 2011. Currently (March 2012) is ongoing at the first ring of cementing drill holes (Fig. 7). 